\title{
Low-salinity stress in the American lobster, Homarus americanus, after chronic sublethal exposure to cadmium: Biochemical effects
}

\author{
E. Gould \\ National Marine Fisheries Service, Northeast Fisheries Center; \\ Milford Laboratory, Milford, Connecticut 06460, USA
}

\begin{abstract}
Lobsters (Homarus americanus) were exposed to cadmium ( $6 \mu \mathrm{g} \mathrm{I}^{-1}, 30$ days) in flowing seawater, then held for 7 days in aerated "clean" seawater at either ambient $(27 \% 0)$ or low $(17 \%)$ salinity. Cadmium exposure alone (ambient salinity) induced a general elevation of enzyme activity (heart, antennal gland, and muscle $\mathrm{MDH}_{i}$ heart LDH and GPI), despite the probability of some clearance of cadmium from body tissues during the "clean" seawater holding period. Low-salinity alone (non-exposed lobsters) caused a decrease of enzyme activity (AAT, LDH, GPI, PK) in most tissues examined, except for tail muscle IDH, the activity of which was increased, and MDH, which was significantly elevated above ambient controls in all tissues except heart. Most low-salinity effects were observed in tail muscle, and most cadmium effects, in heart; low-salinity effects outnumbered cadmium stress by nine to four. In heart and tail muscle of cadmium-exposed lobsters held at low salinity, each of the two stresses apparently operated to nullify the other's effects. The most prominent single biochemical response to these sublethal stresses was the elevation of $\mathrm{MDH}$ activity. The ratio MDH: LDH gave the clearest indication of overall relative stress.
\end{abstract}

\section{INTRODUCTION}

For the better part of the past decade, we have examined in our laboratory the physiological effects of heavy metals on marine animals (Calabrese et al., in press). Short-term bioassay work led to long-term sublethal exposures to which has been added, in recent years, subsequent challenge by a natural variable. The purpose is to discover how sublethal metal exposure affects an animal's capacity to adapt to environmental change. This report describes such an experiment: a 1-month exposure of American lobsters, Homarus americanus, to sublethal cadmium $\left(6 \mu \mathrm{g}^{-1}\right)$, followed by a 7 -day holding period in seawater of either ambient or low salinity. At very low concentrations, cadmium can alter metabolic patterns in adult marine animals (Calabrese et al., 1977), including the lobster, and also strongly modifies, in Mytilus edulis larvae, life functions that are salinity-dependent (Lehnberg \& Theede, 1979).

The lobster was selected as an osmoconformer that adapts only slowly to changing ionic concentrations. It will, however, survive an abrupt drop in salinity within its tolerance range (Dall, 1970). Milford Harbor water, in which the test animals were acclimated, had an average salinity of $27 \%$ at the time of the experiment; for the lowsalinity challenge, therefore, we selected $17 \%$ as being stressful but well within the lethal limits set for this animal (McLeese, 1956) in fully oxygenated seawater at $20^{\circ} \mathrm{C}$. 
Metabolic response in animal tissue often depends upon environmental salinity. As Munday \& Poat (1971) have pointed out, ". . . not only do tissues from the same species react differently to osmotic variation, but ... effects on one tissue may often mask the effect on others". Four different tissues, therefore, were examined for biochemical change in this study: heart and tail muscle, because muscle amino acids decrease in osmoconformers at low salinity (Prosser, 1973); the antennal gland, because of its regulatory function in ionic balance; and the male gonad, because of the possibility that it may be buffered from the metabolic demands of general stress, as Bayne has observed to be the case with Mytilus edulis (cited in Livingstone, 1975).

Enzymes selected for monitoring in these tissues were almost entirely those of glycolysis, as our primary interest was in energy expenditure. Pyruvate kinase (PK; E.C. 2.7.1.40) and glucosephosphate isomerase (GPI ${ }_{i}$ E.C. 5.3.1.9) stand at either end of the Embden-Meyerhof pathway of anaerobic glycolysis; glucose-6-phosphate dehydrogenase (G6PDH; E.C. 1.1.1.49) is the magnesium-modulated regulator of pentose shunt activity; malate dehydrogenase $(\mathrm{MDH} ;$ E.C. 1.1.1.37) and lactate dehydrogenase ( $\mathrm{LDH}$; E.C. 1.1.1.27) are closely involved in cellular redox regulation, providing the oxidized coenzyme that is essential for continuing glycolysis; and NADP-linked isocitrate dehydrogenase (IDH; E.C. 1.1.1.42) represents the citric acid cycle. Transamination, the most important means of initiating amino acid catabolism (Banks et al., 1976), was monitored in the lobster heart, using aspartate aminotransferase (AAT; E.C. 2.6.1.1.).

\section{MATERIALS AND METHODS}

Animal exposure. Lobsters were collected by trap from the waters of Long Island Sound near Milford, Connecticut (USA), and acclimated in the laboratory in flowing, sand-filtered seawater for one to two weeks before experimental exposure. They were fed chopped clams (Spisula solidissima) daily during acclimation and throughout the exposure period. Test animals were exposed to cadmium $\left(6 \mu \mathrm{g} \mathrm{l}^{-1}\right)$ as cadmium chloride in a flow-through system as described by Thurberg et al. (1977). Sixteen lobsters served as controls (4 animals per 285-l fiberglass tank) and the same number for cadmium exposure in each of the duplicate experimental series. Salinity and temperature ranges during the 30-day exposure periods were $25.9-27.5 \%$ and $11.2-18.2$ ${ }^{\circ} \mathrm{C}$, respectively, for the first series, and $25.7-28.5 \%$ and $14.0-23.2{ }^{\circ} \mathrm{C}$ for the second. Temperature range during both 7-day holding periods, at either ambient or low salinity, was $18-23^{\circ}$.

At the end of the first experimental exposure, the control lobsters were removed in three lots over three consecutive days $(29,30$, and 31 days' exposure), color-coded with rubber bands to designate the day of removal, and placed in a large fiberglass holding tank containing aerated water at low salinity $(17 \%)$. The cadmium-exposed lobsters were removed in like fashion and placed in another large tank with aerated, low-salinity seawater. Animals from the second experimental exposure were similarly handled, but placed in aerated water of ambient salinity $(27 \pm 0.5 \%$ ). The water was changed daily, both low salinity and ambient, and the animals were fed chopped clams every other day. After 7 days, the lobsters for each series were removed in three lots over three consecutive days and their tissues dissected, packaged in air-tight plastic bags, and frozenstored at $-80^{\circ} \mathrm{C}$ to await testing. 
Tis sue preparation. Tissues were homogenized as follows: antennal gland, $1: 9, \mathrm{w} / \mathrm{v}$, in cold $0.25 M$ sucrose containing $2.4 \mathrm{mMNa}$ deoxycholate; heart, $1: 19$ in cold, doubly glass-distilled water; tail muscle, 1:4, also in cold water; and male gonads, 1:9 in cold $1 \%$ Triton, a non-ionic surfactant (W-1339, Ruger Chemical Company, Irvingtonon-Hudson, N. Y.) ${ }^{*}$. All tissues were prepared in small all-glass homogenizers containing a small amount of 25-nm glass powder. Centrifugation at $4{ }^{\circ} \mathrm{C}$ was at $20,000 \mathrm{~g}$ for 45 min for antennal gland and heart, and $32,000 \mathrm{~g}$ for $60 \mathrm{~min}$ for tail muscle and male gonads. The clear supernates served as the crude enzyme preparations, and protein content was determined by the biuret method (Gornal et al., 1949, cited in Layne, 1957).

Enzyme assays. All solutions were made in doubly glass-distilled water. Biochemicals were obtained from Sigma Chemical Company, St. Louis, Mo. * Activities of all enzymes were determined by fixed-wavelength spectrophotometry using pyridine nucleotide coenzymes either directly or by a coupled-assay procedure; assay temperature was $25^{\circ} \mathrm{C}$. Unit of activity in each case was $\mu$ mole $\mathrm{NAD}(\mathrm{P})^{*}{ }^{*}$ reduced or $\mathrm{NADH}$ oxidized per min per $\mathrm{mg}$ biuret protein. Assay concentrations $(\mathrm{m} M)$ in a $3.00-\mathrm{ml}$ reaction volume were: $\mathrm{MDH}, \mathrm{LDH}, \mathrm{GPI}$, and PK - as in Gould \& Nitkowski (1979), except for PK substrate concentrations ADP, 0.23, and PEP, 0.80; AAT - K phosphate buffer $\mathrm{pH} 7.5$, $100 ; \mathrm{K}$ aspartate, 200; NADH, 0.30; $\propto \mathrm{KG}, 6.7 ; 96 \mu \mathrm{M}$ units $\mathrm{MDH}$ (Sigma \# 410-9); IDH Tris buffer $\mathrm{pH} 8.0,90 ; \mathrm{NADP}, 0.3 ; \mathrm{MnCl}_{2}, 3.3 ; \mathrm{NaCl}, 5.0 ;$ IsoC, $5.0 ; \mathrm{G6PDH}-$ as in Gould \& Nitkowski (1979), except substrate concentrations G6P, 0.04 and 0.40. Determination of statistical significance was made using Student's $t$-test.

\section{RESULTS}

Tail-muscle enzymes examined were generally influenced more strongly by lowsalinity stress than by sublethal cadmium exposure. Elevation of MDH activity was the only observed effect that could be attributed to cadmium exposure alone, an effect also seen in control animals at low salinity; and together, these stresses elevated the activity to a greater degree than did either stress alone, for an additive effect (Fig. 1a). Muscle LDH activity was depressed by low-salinity stress in both control and cadmium-exposed animals (Fig. 1b); cadmium exposure did not affect this enzyme activity. Low salinity depressed the activity of GPI only in control animals (Fig. 1c), an effect abolished by cadmium exposure, although cadmium exposure alone did not affect GPI activity. There was no cadmium effect on the activity of either PK or IDH in this tissue at ambient salinity (Table 1), but low salinity inhibited PK both in controls and in cadmium-exposed lobsters, and stimulated IDH in the controls, with what appeared to be an additive effect with cadmium, in the metal-exposed animals.

In the lobster heart, cadmium exposure caused more metabolic changes than in the tail muscle, and more than low salinity alone. MDH, LDH, and GPI activities were all

\footnotetext{
* Reference to trade names does not constitute endorsement by the NMFS, NOAA

** Abbreviations used: NAD(P), nicotinamide adenine dinucleotide (phosphate); NADH, reduced NAD; Tris, tris (hydroxymethyl) aminomethane; ADP, adenosine 5'-diphosphate; PEP, phospho(enol) pyruvate, tricyclohexylamine salt; F6P, dl-fructose-6-phosphate, potassium salt; $\propto \mathrm{KG}$, $\propto$ ketoglutaric acid, potassium salt; IsoC, dl-isocitric acid, sodium salt; G6P, d-glucose-6-phosphate, monosodium salt; $K_{m}$, substrate concentration at one-half maximal velocity, $V_{\text {max }}, M$, tail muscle; $H$, heart; $A G$, antennal gland; $M G$, male gonad
} 

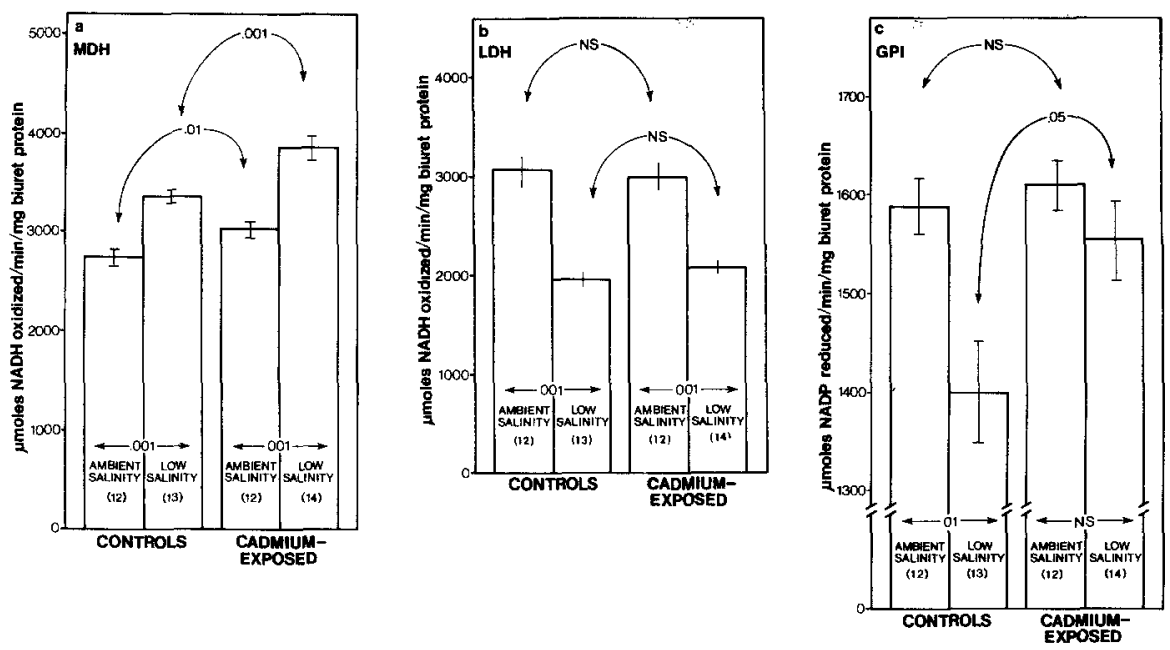

Fig. 1. Effects of sublethal cadmium exposure and of low salinity, individually and combined, on enzymes in lobster tail muscle. Bar height represents arithmetic mean, and the ticked vertical lines, standard error. Numerals in parentheses are sample number. Level of confidence is inserted in each arrow connecting a pair of bars, representing compared data sets. The same conventions are observed for Figures 2-4

stimulated by the sublethal metal stress (Figs. 2a, 2b, 2c), whereas low salinity depressed heart LDH (Fig. 2b) and AAT (Fig. 2d) in control lobsters. Low salinity abolished the effect of cadmium on heart LDH and GPI but did not change the cadmium-induced elevation of $\mathrm{MDH}$ activity. Cadmium exposure did not influence AAT activity.

In antennal glands, either cadmium exposure or low salinity alone produced an elevation of $\mathrm{MDH}$ activity, but this effect was significantly diminished when both stresses were combined (Fig. 3a). Antennal gland LDH, on the other hand, was not affected by either stress alone, but the two together acted to inhibit LDH activity (Fig. $3 b$ ). The result of the combined stress in lobster antennal gland in each of these cases, therefore, was repressive synergism. Under optimal assay conditions. G6PDH activity in the antennal gland showed no significant effects either for cadmium exposure or for low salinity. Activation by a tenfold increase in assay concentration of substrate (from 0.04 to

Table 1. Effects of cadmium exposure $\left(6 \mu \mathrm{g} \mathrm{l}^{-1}\right)$ and of low salinity $(17 \%)$ on pyruvate kinase and isocitrate dehydrogenase in lobster tissues

\begin{tabular}{|c|c|c|c|}
\hline Tissue & $\begin{array}{c}\text { Cadmium effect } \\
\text { (at ambient salinity) }\end{array}$ & $\begin{array}{l}\text { Low-salinity effect } \\
\text { (in controls) }\end{array}$ & $\begin{array}{l}\text { Cadmium effect } \\
\text { at low salinity }\end{array}$ \\
\hline \multicolumn{4}{|c|}{ PK } \\
\hline Heart & None & None & None \\
\hline Muscle & None & $\downarrow$ Depressed activity $(<.05)$ & $\downarrow$ LS Effect only \\
\hline Male gonad & None & None & None \\
\hline \multicolumn{4}{|c|}{$\mathrm{IDH}$} \\
\hline Muscle & None & $\uparrow$ Elevated activity $(<.05)$ & $\uparrow$ Additive $(<.02)$ \\
\hline
\end{tabular}



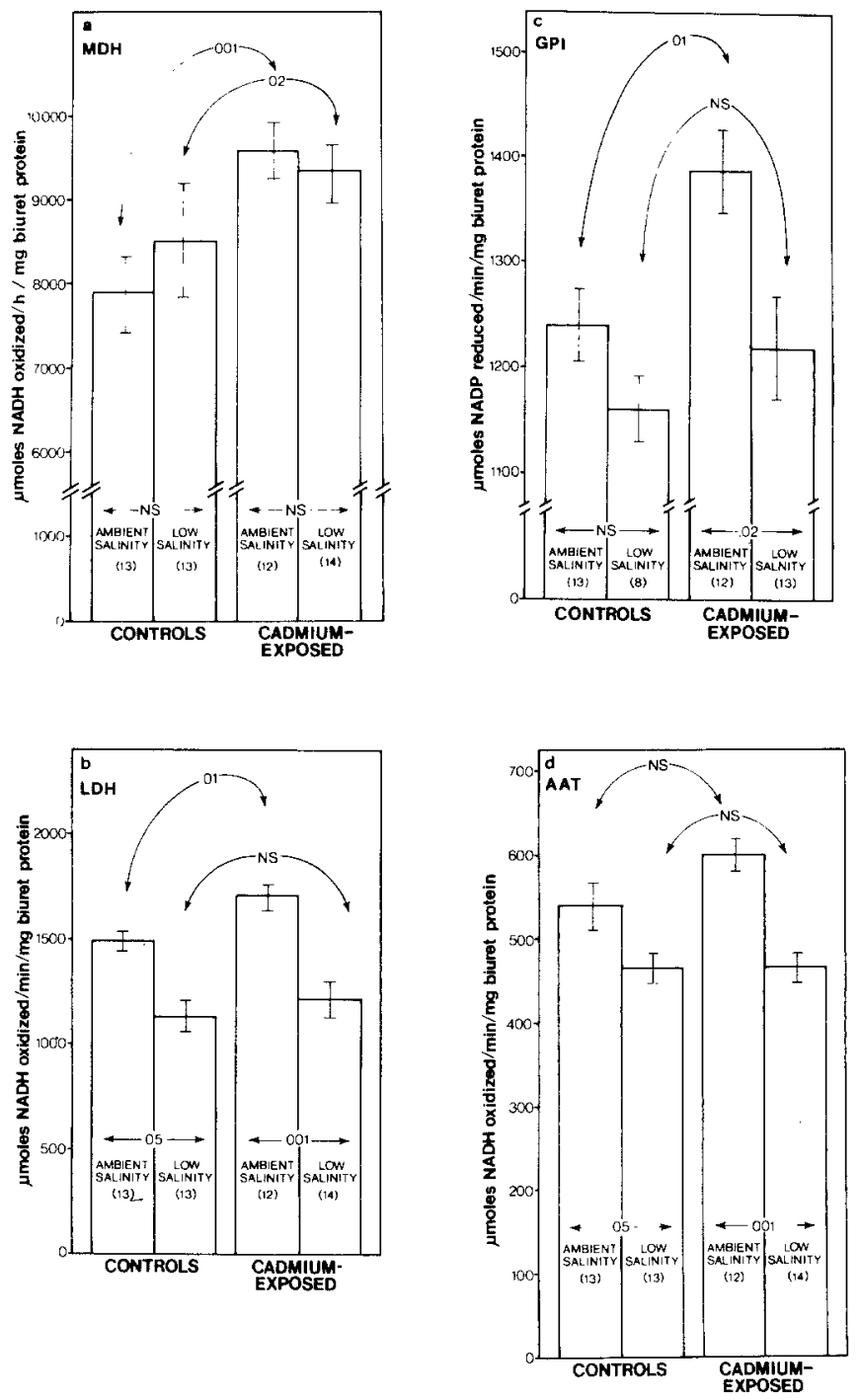

Fig. 2. Effects of sublethal cadmium exposure and of low salinity, individually and combined, on enzymes in lobster heart

$0.40 \mathrm{mM})$, however, was significantly higher $(P<0.05)$ in the low-salinity controls $(72.0 \%)$ as compared with ambient-salinity controls $(58.4 \%)$, whereas values for the cadmium-exposed animals, at both ambient $(70.0 \%)$ and low-salinity $(67.5 \%)$, did not differ significantly from either ambient or low-salinity controls.

In Figures $4 a, 4 b$, and $4 c$, it is clear that there was no cadmium effect at ambient salinity on three enzymes tested from male gonad (MDH, LDH, and GPI). Low salinity elevated MDH activity in both control and cadmium-exposed lobsters, and depressed LDH in control animals, an effect that disappeared in the cadmium-exposed animals. Combined, the two stresses elevated GPI activity, another synergism. 

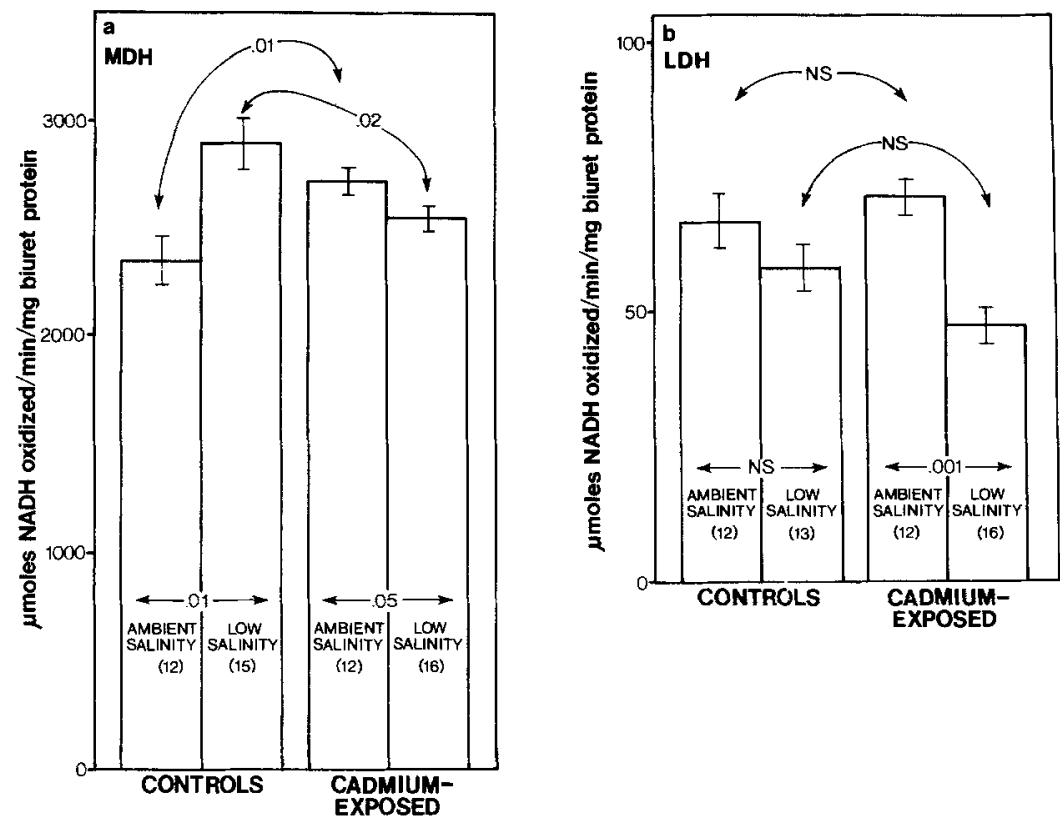

Fig. 3. Effects of sublethal cadmium exposure and of low salinity, individually and combined, on enzymes in lobster antennal gland
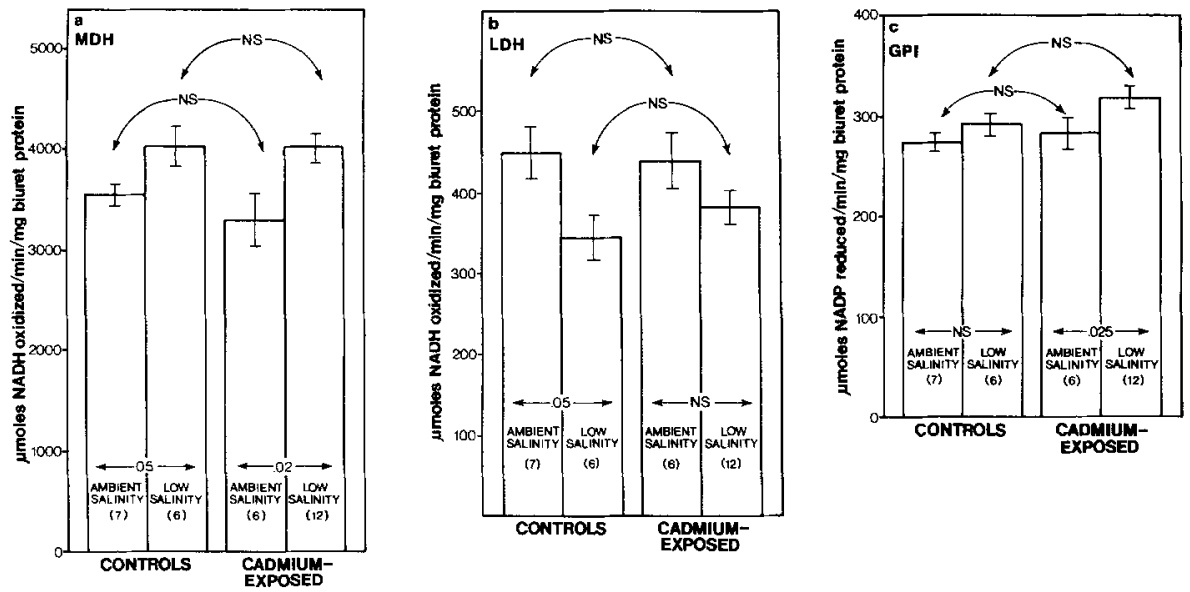

Fig. 4. Effects of sublethal cadmium exposure and of low salinity, individually and combined, on enzymes in male lobster gonad

\section{DISCUSSION}

The general characteristic of low-salinity stress in otherwise untreated lobsters was an inhibition of most of the enzymes examined (Table 2), with the exception of MDH in all tissues and tail muscle IDH. Cripps \& Reish (1973) found that LDH activity decreased in a marine polychaete held under either hyperosmotic or hyposmotic conditions, and that $\mathrm{MDH}$ isoenzymes varied in their response: cytoplasmic (s) MDH decreased slightly, 
and mitochondrial (m) MDH increased under both forms of osmotic stress. Their observation prompts the speculation that $\mathrm{MDH}$ activity observed in the present study was predominantly the mitochondrial form, which is associated with the citric acid cycle; this interpretation is supported by the concurrent elevation of another citric acid cycle enzyme, IDH. Increased activity of this cycle with decreasing osmolarity has been reported in isolated crab-gill mitochondria, accompanied by increased oxygen consumption (King, 1966). Moreover, both MDH and IDH in aquatic arthropods are reported to be inhibited by increased cellular ionic concentrations (Schoffeniels \& Gilles, 1970b); analogous reasoning suggests the dominance of $\mathrm{sMDH}$ in the muscle tissue of marine crustaceans under hyperosmotic conditions and, conversely, of mMDH under hyposmotic conditions. The decrease in heart AAT activity observed in both control and cadmium-exposed lobsters at low salinity supports earlier observations that transaminase activities (in marine bivalves) are proportional to the rates of loss of amino acids (Hammen, 1969), and that amino acid concentrations (in euryhaline invertebrates) decrease during hyposmotic stress (Schoffeniels \& Gilles, 1970a; Gilles, 1973).

Hypoxic stress can exert biochemical effects that are disconcertingly similar to those here attributed to low salinity: Blackstock (1978) reported a significantly lower AAT activity in a marine polychaete that had been experimentally subjected to hypoxic conditions, and a lower PK in the same species field-collected from sediments at a polluted, often hypoxic site, than was seen in worms taken from less stressed areas. Inhibition of LDH activity, too, is a common event in cells geared toward anaerobiosis (Schoffeniels \& Gilles, 1970b), as is also the case with PK (Hochachka \& Somero, 1973). Yet during the 7-day holding period at the two salinities, the water was continuously aerated, as well as changed daily. The ambient-salinity tanks, $27.5 \%$ at an average $21^{\circ}$, had a dissolved oxygen concentration of $7.57 \mathrm{ppm}$, according to Green \& Carritt (1967); in the low-salinity tanks, at $17 \%$ and $20^{\circ} \mathrm{C}$, it was $8.24 \mathrm{ppm}$. The animals, therefore, were not hypoxic; the observed stress can reasonably be attributed to low salinity.

Tissues of lobsters exposed to sublethal cadmium and subsequently held for 7 days (clearing) at ambient salinity, on the other hand, showed marked elevation in the activity of glycolytic enzymes (Table 2). In earlier experimentation with cadmium-exposed

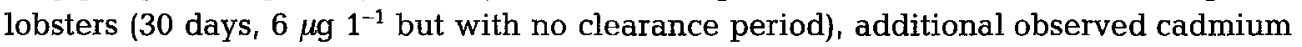
effects were also stimulatory, on male gonad LDH and tail muscle PK and GPI (Gould, unpublished data). The major overall effect of sublethal cadmium stress in all lobster tissues examined, then, was increased glycolysis, an expenditure of energy reserves typical of many types of sublethal stress, as in the cold-acclimation of terrestrial invertebrates (Rao, 1966). This observation accords with Theede's report (1980) of an increased gross energy demand in cadmium-fed Mytilus larvae, and with that of Price \& Uglow (1980) of increased rate of heart beat in cadmium-exposed Crangon.

Jointly, the two stresses (sublethal cadmium and low salinity) operated to produce a variety of effects in all tissues examined (Table 2). Two especially noteworthy effects were observed in the antennal gland of cadmium-exposed lobsters at low salinity. Firstly, although sublethal cadmium exposure and low salinity individually caused elevation of $\mathrm{MDH}$ activity, together they acted synergistically to depress it. The activity was not depressed below ambient-control levels, although a longer period of subjection to the double stress might have done so; the significant fact here, however, is that the normal response of the lobster antennal gland to each of the two sublethal stresses 
Low-salinity. stress

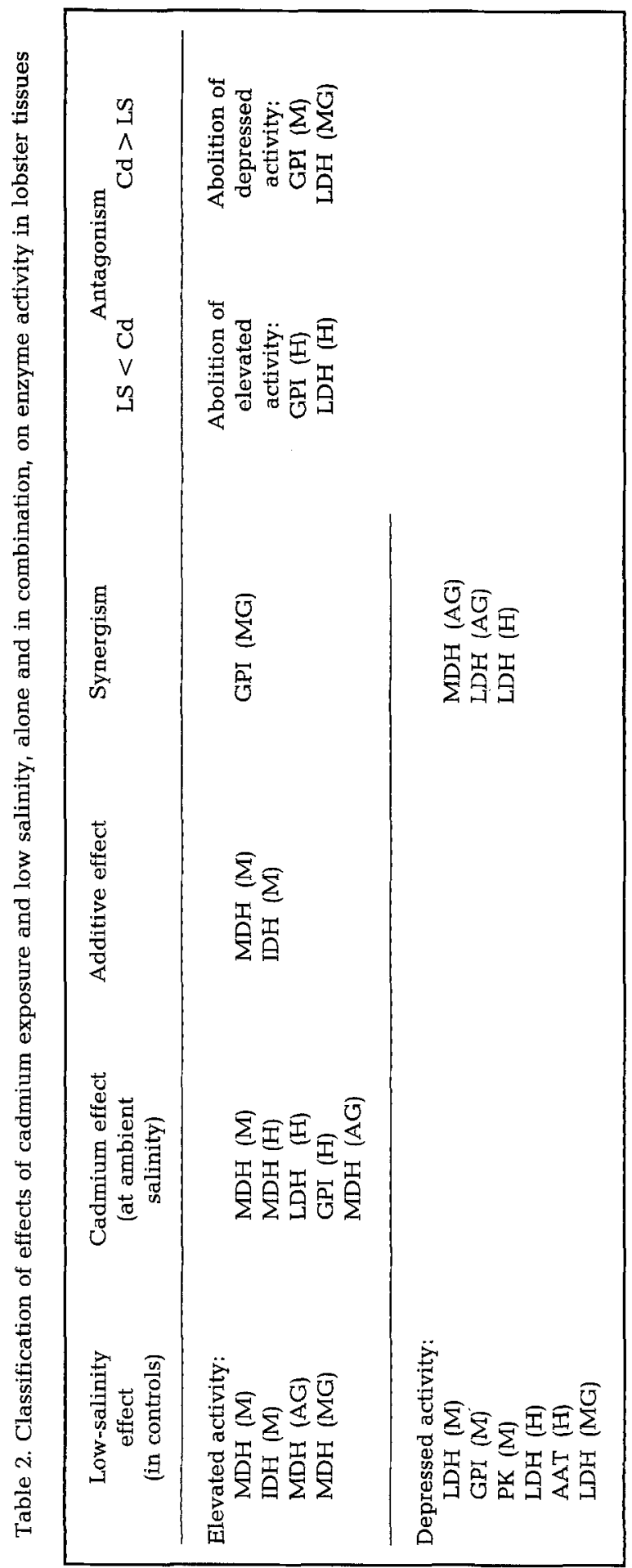


individually was MDH elevation, and that this response was significantly blunted by the double stress. Moreover, LDH activity was also depressed. Concurrent inhibition of these two redox regulators indicates a diminished capacity for regenerating oxidized NAD and, consequently, limited glycolytic efficiency (Banks et al., 1976). The second effect of the double stress in the antennal gland was the weakening of an enzyme-ligand affinity. The prior work with cadmium-exposed lobsters, mentioned above, showed a significant loss of sensitivity to magnesium modulation $\left(\mathrm{K}_{\mathrm{m}}, P<0.01, \mathrm{~V}_{\max }, P<0.001\right)$ in antennal gland G6PDH (Gould, unpublished data), similar to that found in the kidney-pronephros of cadmium-exposed (60 days, $10 \mathrm{ppb}$ ) winter flounder, Pseudopleuronectes americanus (Gould \& Nitkowski, 1979). Preparations of antennal gland from lobsters in the present report, insufficient for performing similar kinetic studies, were used instead to test G6PDH substrate activation. The substrate-activation figures (see section "Results") suggest a protective mechanism at low-salinity for enzyme-substrate affinity that is present in control but not in cadmium-exposed lobsters. An analogous loss of ligand sensitivity was reported for heart AAT in lobsters similarly exposed to sublethal cadmium (Thurberg et al., 1977).

Perhaps the most prominent single biochemical response to sublethal stress was the elevation of MDH activity, a stress signal that in this study was often accompanied by depression of $\mathrm{LDH}$ activity. The ratio of these two enzyme activities, MDH: LDH (Table 3), constitutes a fairly accurate reflection of the degree of stress: Cd-LS $>$ Control-LS $>$ CdAmbient>Control-Ambient. Oxygen consumption of gill tissue from the lobsters in this study confirms this order of stress: Cd-LS (1323 $\left.\mu \mathrm{l} \mathrm{h}^{-1} \mathrm{~g}^{-1}\right)$, Control-LS (1104), CdAmbient (772), and Control-Ambient (703) (F. P. Thurberg, personal communication), and the only significant difference in hematological parameters was an increase in $\mathrm{Na}^{+}$ in the cadmium-exposed lobsters at low salinity (M. A. Dawson, personal communication).

Roberts (1964) has commented that like metabolic systems in different tissues in the same species, and in like tissues in different species, may operate to produce diverse effects because of the varying degrees of systemic control. This is undoubtedly true for the observations in this study, and it would be unwise to attempt any firm conclusions. Nevertheless, one might profitably consider the following paradox: Elevation of enzyme activity (including abolition of depression) by the combined stresses was evident only in the tail muscle and male gonad; yet in this study, such elevation was the hallmark of sublethal cadmium stress, and tail muscle was the tissue in which low-salinity stress was most prominent. Conversely, inhibition of enzyme activity (including abolition of

Table 3. Effects of cadmium exposure and of low salinity on the ratio of MDH : LDH activities in lobster tissues

\begin{tabular}{|lrrrr|}
\hline \multicolumn{1}{c}{ Tissue } & Control-Ambient & Cd-Ambient & Control-LS & Cd-LS \\
\hline Heart & 5.31 & 5.61 & 7.49 & 7.77 \\
Muscle & 0.89 & 1.01 & 1.75 & 1.87 \\
Antennal gland & 35.32 & 38.00 & 49.98 & 53.53 \\
Male gonad* & 7.96 & 7.52 & 11.74 & 10.53 \\
"No cadmium effect was observed in the male gonad & & \\
\hline
\end{tabular}


increased activity) was seen only in the heart and antennal gland; yet such inhibition was observed to be the major effect of low salinity, and the heart was where cadmium effects were the most numerous. It thus appears that in the general muscle metabolism of this decapod crustacean, the effects of one sublethal stress tend to offset those of the other.

Acknowledgements. I am grateful to M. Nitkowski and N. A. Rawson for their expert technical assistance, and to Dr. John J. Stegeman, Woods Hole Oceanographic Institution, for a critical review of the manuscript.

\section{LITERATURE CITED}

Banks, P., Bartley, W. \& Birt, L. M., 1976. The biochemistry of the tissues. Wiley, London, 493 pp. Blackstock, J., 1978. Activities of some enzymes associated with energy yielding metabolism in Glycera alba (Müller) from three areas of Loch Eil. In: Physiology and behaviour of marine organisms. Ed. by D. S. McLusky \& A. J. Berry. Pergamon Press, Oxford, 11-20.

Calabrese, A., Gould, E. \& Thurberg, F. P. Heavy-metal effects in marine animals of the New York Bight. In: Ecological stress in the New York Bight: science and management. Proceedings, MESA Symposium "Ecological effects of environmental stress", June 10-15, 1979. (In press.)

Calabrese, A., Thurberg, F. P. \& Gould, E., 1977. Effects of cadmium, mercury, and silver on marine animals. - Mar. Fish. Rev. 39, 5-11.

Cripps, R. A. \& Reish, D. J., 1973. The effect of environmental stress on the activity of malate dehydrogenase and lactate dehydrogenase in Neanthes arenaceodentata (Annelida: Polychaeta). - Comp. Biochem. Physiol. 46B, 123-133.

Dall, W., 1970. Osmoregulation in the lobster Homarus americanus. - J. Fish. Res. Bd Can. 27, 1123-1130.

Gilles, R., 1973. Oxygen consumption as related to the amino-acid metabolism during osmoregulation in the blue crab, Callinectes sapidus. - Neth. J. Sea Res. 7, 280-289.

Gould, E. \& Nitkowski, M., 1979. Changing enzyme activities in maturing gonads of the winter flounder, Pseudopleuronectes americanus. In: Cyclic phenomena in marine plants and animals. Ed. by E. Naylor \& R. G. Hartnoll. Pergamon Press, Oxford, 231-238.

Green, E. J. \& Carritt, D. E., 1967. New tables for oxygen saturation of seawater. - J. mar. Res. 25, $140-147$.

Hammen, C. S., 1969. Metabolism of the oyster, Crassostrea virginica. - Am. Zool. 9, 309-318.

Hochachka, P. W. \& Somero, G. N., 1973. Strategies of biochemical adaptation. Saunders, Philadelphia, $358 \mathrm{pp}$.

King, E. N., 1966. Oxidative activity of crab gill mitochondria as a function of osmotic concentration. - Comp. Biochem. Physiol. 17, 245-258.

Layne, E., 1957. Spectrophotometric and turbidimetric methods for measuring proteins. III. Biuret method. In: Methods in enzymology. Ed. by S. P. Colowick \& N. O. Kaplan. Acad. Press, New York, 3, 450-451.

Lehnberg, W. \& Theede, H., 1979. Kombinierte Wirkungen von Temperatur, Salzgehalt und Cadmium auf Entwicklung, Wachstum und Mortalität der Larven von Mytilus edulis aus der westlichen Ostsee. - Helgoländer wiss. Meeresunters. 32, 179-199.

Livingstone, D. R., 1975. A comparison of the kinetic properties of pyruvate kinase in three populations of Mytilus edulis L. for different environments. In: Proceedings 9th European marine biology symposium. Ed. by Harold Barnes. Aberdeen Univ. Press, Aberdeen, 151-164.

McLeese, D. W., 1956. Effects of temperature, salinity, and oxygen on the survival of the American lobster. - J. Fish. Res. Bd Can. 13, 247-272.

Munday, K. A. \& Poat, P. C., 1971. Respiration and energy metabolism in crustacea. In: Chemical zoology. Ed. by M. Florkin \& B. T. Scheer. Acad. Press, New York, 6, 191-211.

Price, R. K. J. \& Uglow, R. F., 1980. Cardiac and ventilatory responses of Crangon crangon to cadmium, copper, and zinc. - Helgoländer Meeresunters. 33, 59-67.

Prosser, C. L., 1973. Water: osmotic balance; hormonal regulation. In: Comparative animal physiology. Ed. by C. L. Prosser. Saunders, Philadelphia, 1-78. 
Rao, K. P., 1966. Some aspects of the biochemical basis of metabolic adaptation. - Helgoländer wiss. Meeresunters. 14, 439-450.

Roberts, J. L., 1964. Metabolic responses of fresh-water sunfish to seasonal photoperiods and temperatures. - Helgoländer wiss. Meeresunters. 9, 459-473.

Schoffeniels, E. \& Gilles, R., 1970á. Nitrogenous constituents and nitrogen metabolism. In: Chemical zoology. Ed. by M. Florkin \& B. T. Scheer. Acad. Press, New York, 5, 199-227.

Schoffeniels, E. \& Gilles, R., 1970b. Osmoregulation in arthropods. In: Chemical zoology. Ed. by M. Florkin \& B. T. Scheer. Acad. Press, New York, 5, 255-286.

Theede, H., 1980. Physiological responses of estuarine animals to cadmium pollution. - Helgoländer Meeresunters. 33, 26-35.

Thurberg, F. P., Calabrese, A., Gould, E., Greig, R. A., Dawson, M. A. \& Tucker, R. K., 1977. Response of the lobster, Homarus americanus, to sublethal amounts of cadmium and mercury. In: Physiological responses of marine biota to pollutants. Ed. by F. J. Vernberg, A. Calabrese, F. P. Thurberg \& W. B. Vernberg. Acad. Press, New York, 185-197. 